\title{
Mercury Pollution Near an Industrial Source in Southwest Finland
}

\author{
Hynninen, V.
}

Springer-Verlag New York Inc.

1986

Hynninen, V. and Lodenius, M. 1986. Mercury Pollution Near an Industrial Source in

Southwest Finland. Bulletin of Environmental Contamination and Toxicology 36: 294-298.

http://hdl.handle.net/1975/202

Downloaded from Helda, University of Helsinki institutional repository.

This is an electronic reprint of the original article.

This reprint may differ from the original in pagination and typographic detail.

Please cite the original version. 


\title{
Mercury Pollution Near An Industrial Source In Southwest Finland
}

\author{
Veikko Hynninen ${ }^{1}$ and Martin Lodenius ${ }^{2}$ \\ 1Department of Botany, University of Helsinki, Fabianinkatu 24 A, SF-00170 \\ Helsinki, Finland and 2Department of Environmental Science, University of \\ Helsinki, Viikki, SF-00710 Helsinki, Finland
}

Mercury is very sparse in Finnish rocks and soils. Some mercury occurs in the ore of the Outokumpu mine, SE Finland. Metal ore from this mine is refined in the metallurgical plants at Kokkola and Harjavalta. Elevated mercury contents have been observed in the environment of the plant at Kokkola (Laamanen et al. 1972, Kling et al. 1984) but no data have been published about the possible mercury contamination around the Harjavalta plant.

\section{MATERIALS AND METHODS}

Harjavalta is situated in SW Finland on the shore of the Kokemäenjoki river. Two large plants are situated in the same area: a metallurgical plant producing copper and nickel and a chemical plant producing sulfuric acid, Al-sulfate and fertilizers.

The prevailing winds are from the southwest (Fig. 1) but the wind often follows the river valley, which is a remarkable wind tunnel for the spreading of air pollutants. The differences in altitude are small $(5-10 \mathrm{~m})$ along the river valley and $10-50 \mathrm{~m}$ elsewhere (Tikkanen 1981).

Moss bags have been successfully used as monitors of airborne mercury (Bull et al.1977, Lodenius \& Tulisalo 1984, Mäkinen \& Lodenius 1984) and this method is especially useful in areas like Harjavalta, where the natural vegetation is largely destroyed.

The moss bags were made of Sphagnum girgensohnii according to Mäkinen (1977). Moss bags were hung in trees at a height of $3-4 \mathrm{~m}$ and placed at 26 sites during two time periods: 22.6.-21.9.1981 and 21.9.1981-20.3.1982. The moss bags were placed at distances of 0.3-9.1 km from the factories. Control moss bags were hung for the same periods of time at Kiikoinen, $26 \mathrm{~km}$ north east of Harjavalta.

The moss material was dried in $+40^{\circ} \mathrm{C}$, homogenized and digested in concentrated $\mathrm{H}_{2} \mathrm{SO}_{4}$ and $\mathrm{HNO}_{3}$ using an aluminium hot bloc $\left(+105^{\circ} \mathrm{C}\right)$. The mercury contents were analysed using cold vapor atomic absorption spectrometry (Coleman MAS-50). 

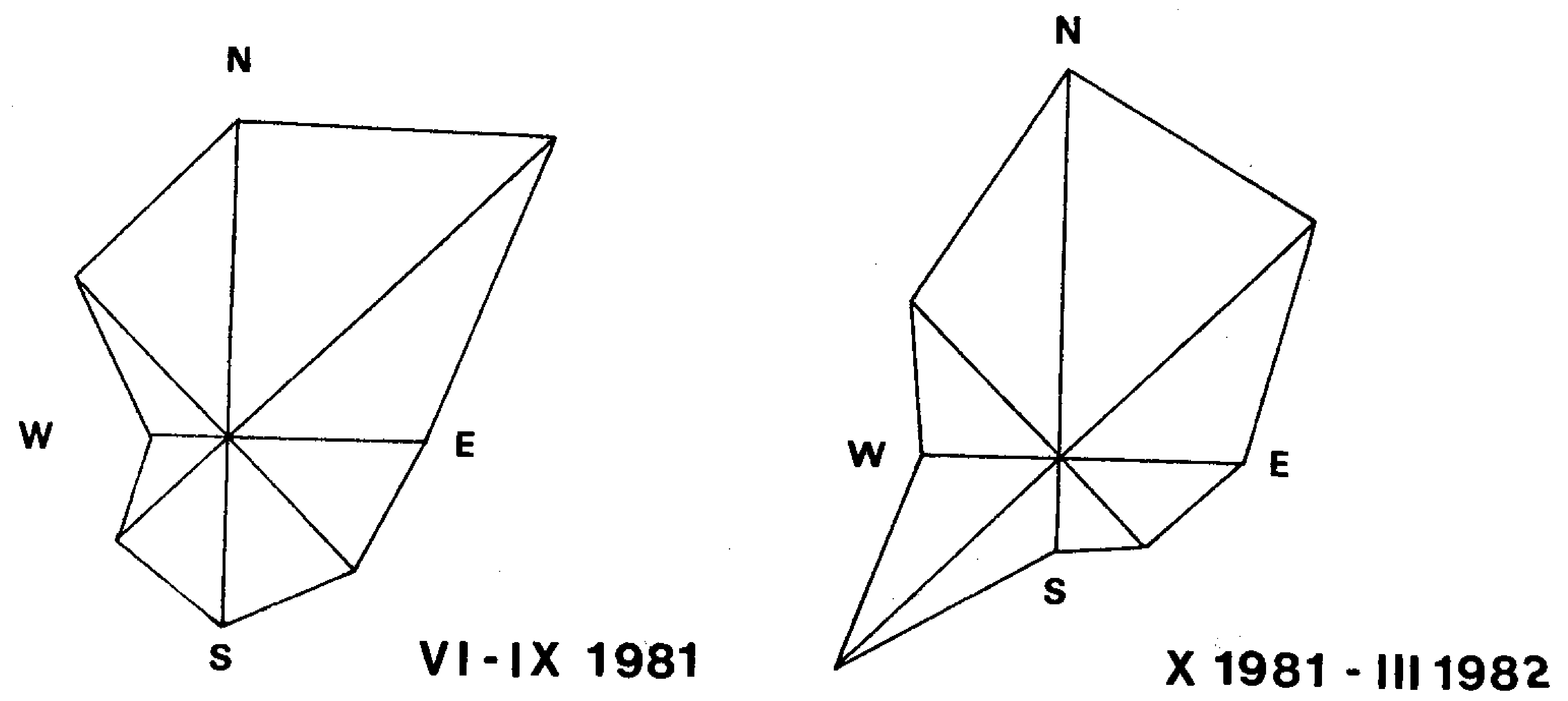

Figure 1. Reverse wind roses from Peipohja, $11 \mathrm{~km}$ south east of Harjavalta.

\section{RESULTS AND DISCUSSION}

In unpolluted areas no essential changes in the mercury content occur in moss bags (Lodenius \& Tulisalo 1984, Mäkinen \& Lodenius 1984 ) and this zero level was also achieved at the sites that were situated far away from the industrial plants in Harjavalta. The maximum accumulation of mercury in the moss bags near the factories was $1.5 \mu \mathrm{g} \mathrm{g}^{-1}$ month $^{-1}$, which was higher than near a chlor-alkali plant (estimated $\mathrm{Hg}$-emission $400 \mathrm{~kg}$ ), where the maximum value was $1.3 \mathrm{\mu g} \mathrm{Hg} \mathrm{g}$ month $^{-1}$ (Lodenius \& Tulisalo 1984) and higher than in Helsinki near a refuse jncinerator and a coal-fired power plant (max. $0.5 \mu \mathrm{g} \mathrm{Hg} \mathrm{g}^{-1}$ month $^{-1}$; Mäkinen \& Lodenius 1984). The accumu lation of mercury was higher ( $t$-test for paired samples: $t=2.47^{*}$, $d f=38$ ) in the winter than in the summer (Fig. 2). This is partly due to the holiday breaks in July and August.

The mercury accumulation clearly increases with decreasing distance from the factories (Fig. 3). In the winter significantly elevated values were obtained even $9 \mathrm{~km}$ from the factories. The differences in wind directions between summer and winter were reflected in the mercury accumulation in the moss bags. The spatial spreading of mercury was very similar to that of other metals, especially copper and nickel, measured from the same material ( $V$. Hynninen unpubl. data). The spreading pattern for mercury in winter was also similar to the damage zones observed in epiphytic lichens (Laaksovirta \& Silvola 1975).

The emissions of heavy metals from the metallurgical and chemical industry are often considerable. The results indicate an annual emission of several hundred $\mathrm{kg}$ of mercury from these factories (or from one of them). More attention should apparently be paid to the mercury emission from these types of industry. 


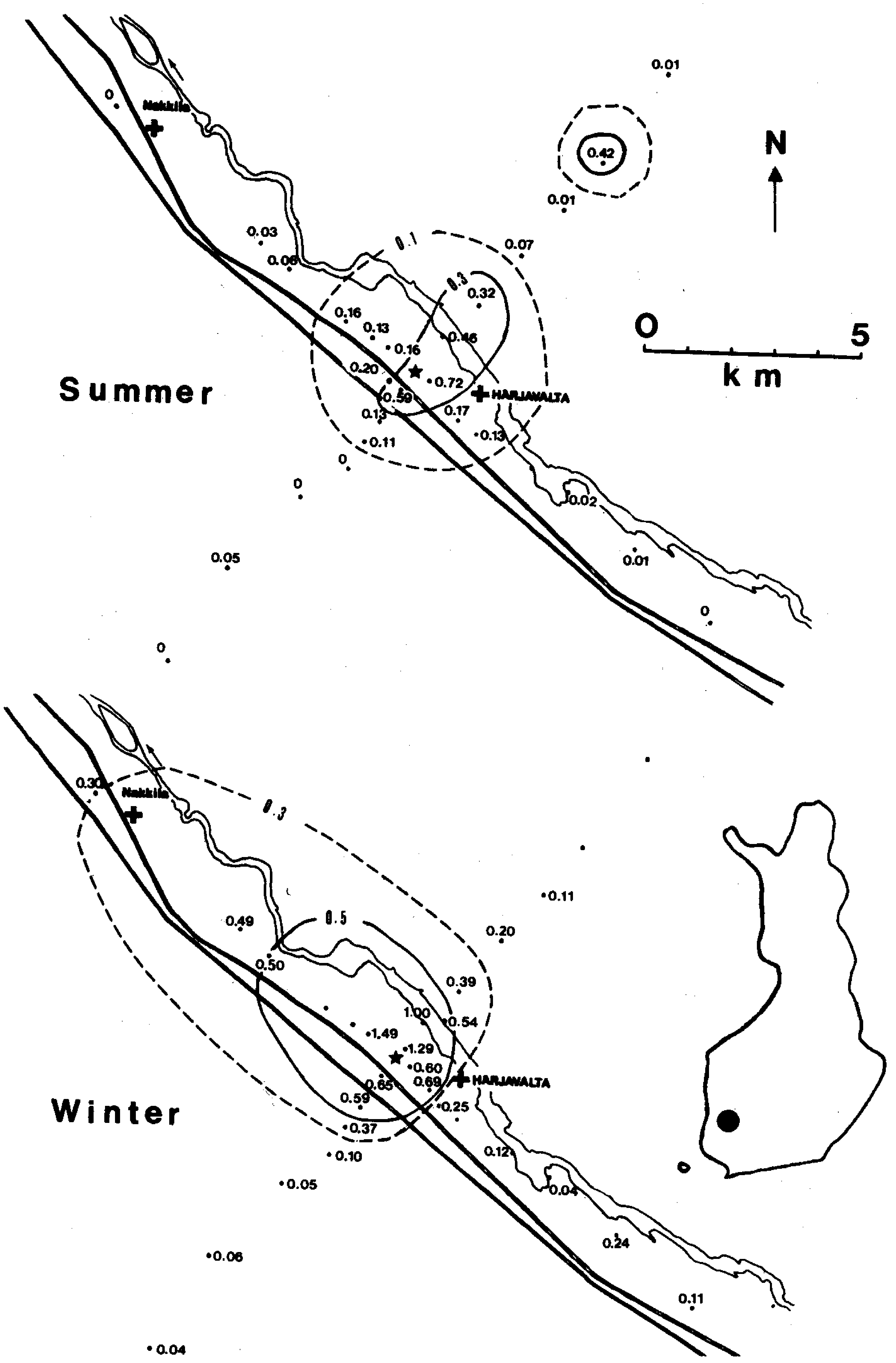

Figure 2. Mercury accumulation ( $\mu \mathrm{Hg} \mathrm{g}^{-1}$ month $^{-1}$ ) in Harjavalta during the two study periods. The communities of Harjavalta and Nakkila, the Kokemäenjoki River, the railway (broken line) and the main road (solid line) are indicated. 


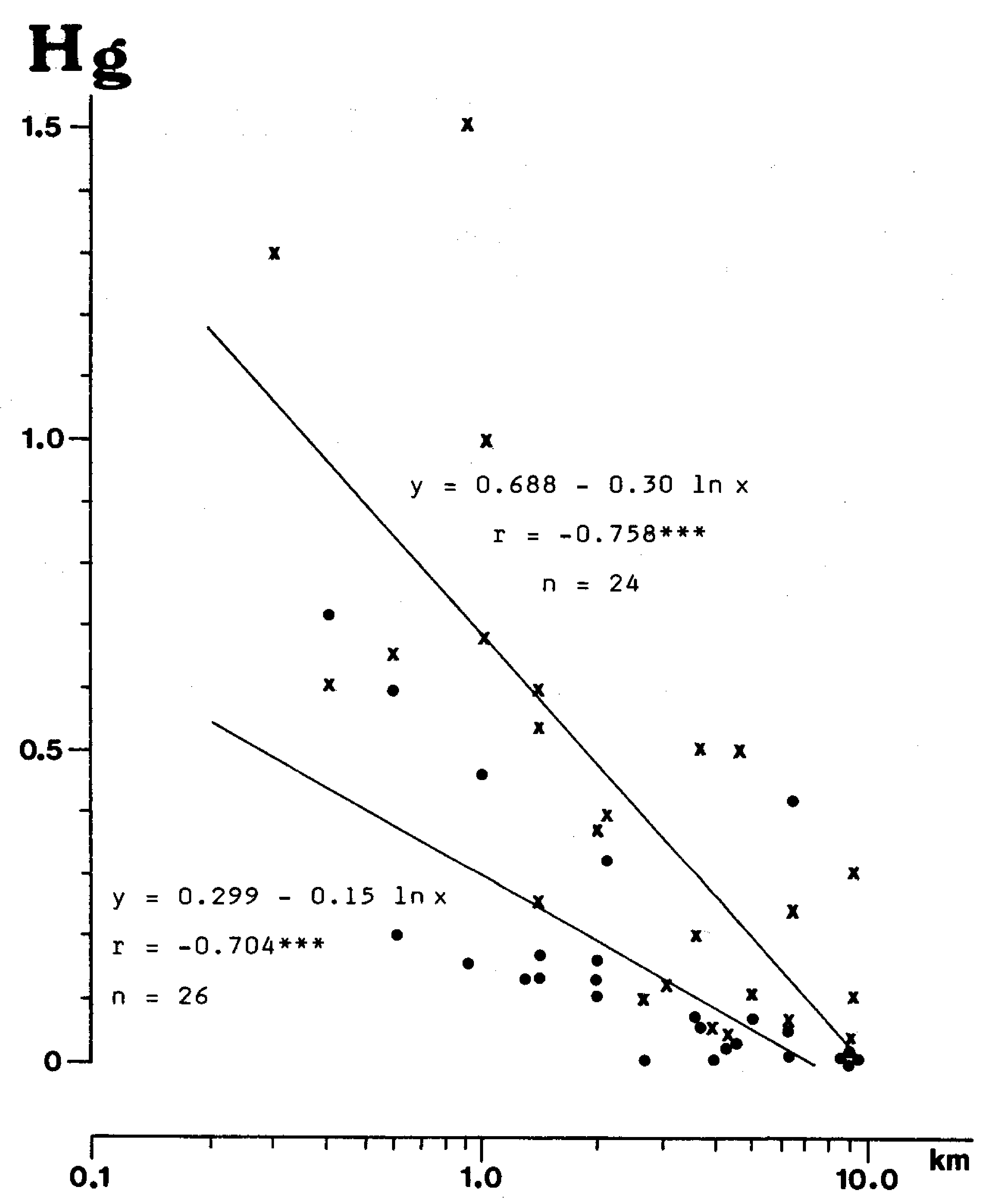

Figure 3. The linear correlations between the mercury accumulation $\mu \mathrm{g} \mathrm{Hg} \mathrm{g^{-1 }}$ month$^{-1}$ ) in moss bags in winter $(\mathbf{X})$ and in summer $(\bullet)$ and the distance (In scale) from the Harjavalta factories.

Acknowledgements. We are indebted to Lic. Phil. Ahti Mäkinen for valuable help in planning the investigation, Mr. Esa Tulisalo for technical assistance and the Academy of Finland for financial support.

\section{REFERENCES}

Bull KR, Roberts RD, Inskip MJ, Goodman GT (1977) Mercury concentrations in soil, grass, earthworms and small mammals near an industrial emission source. Environ Pollut 12:135-140

Kling P, Laaksovirta K, Lodenius M (1984) The effect of air pollution on heavy metal and ash contents of Hypogymnia physodes and bark of 
Pinus sylvestris at Kokkola, W. Finland. Publ Univ Kuopio, Nat Sci, Stat Rev 1/1984:BL5

Laaksovirta K, Silvola J (1975) Effect of air pollution by copper, sulphuric acid and fertilizer factories on plants at Harjavalta, W. Finland. Ann Bot Fennici 12:81-88

Laamanen A, Markkanen K, Riekkinen A-L (1972) The effect of mine-, basic chemical and fertilizer industry on the community air in Kokkola. Rep Inst Occup Health Helsinki 80:1-78

Lodenius M, Tulisalo E (1984) Environmental mercury contamination around a chlor-alkali plant. Bull Environ Contam Toxicol 32:439444

Mäkinen A (1977) Moss- and peat-bags in air pollution monitoring. Suo (Helsinki) 28:79-88

Mäkinen A, Lodenius M (1984) Urban levels of cadmium and mercury in Helsinki determined from moss-bags and feather mosses. Ympäristö ja Terveys (Helsinki) 15:306-317

Tikkanen M (1981) Georelief, its origin and development in the coastal area between Pori and Uusikaupunki, Southwestern Finland. Fennia 159:254-333

Received January 28, 1985; accepted February 25, 1985 